\title{
The Impact of the Integration of Europe on Finnish Labor Policy
}

\section{JUSSI TOPPILA}

Secretary General

Council for Labour Affairs

Ministry of Labour

\section{Introduction}

The integration of Europe and internationalization are consequences of the profound changes which have occurred in technological development and in the structure of production. In many of the most important areas of production the production series must be sufficiently large in order to be able to compete. In the key fields of the economy, the ones faring best are the large multinational enterprises. In order to sell their products, they must find wide enough markets. Economic integration in Europe is based, to a large extent, on these changes in technology and in the economic structure.

Finland's production has been forced to internationalize and Finland will be included in the integration of Europe, no matter what institutionalized decisions are made. The basic problem is what will happen to a small and remote country, when integration strengthens centralizing tendencies on the enterprise level. The changes in production caused by internationalization, as well as the developments in Eastern Europe, will also greatly influence the lives of the workers and the conditions governing their lives. This article will examine the effects of internationalization and the challenges it will bring to bear on Finland's labor policy, mainly in regard to the labor force. The main emphasis will be on questions concerning the mobility of the labor force. In addition, the impact of internationalization on labor legislation, social security and wage policy will be discussed.

\section{Western Europe's labor market regions}

Today there are two labor market regions in Western Europe, the Nordic labor market and the EC-labor market. The Nordic labor market is based on an agreement concerning a joint labor market, dating from 1954. The EC-labor market is based on the Rome agreement of 1958 . There are currently 10 countries belonging to the common EC-labor market and, starting January 1, 1993, there will be a total of 12 member states.

There are 322 million inhabitants in the EC's 12 member states, 220 million of whom are of working age. In the five Nordic countries there are 22 million inhabitants, 12 million of whom are included in the work force. Denmark belongs to both labor market systems. In the EC there are less than 15 million unemployed, with the average unemployment rate about $8-9 \%$ of the work force, while the corresponding Nordic figure is around $4 \%$.

In the last few years the population structure of the EC-labor market has been characterized by the arrival of young people on the labor market and the strong in- 
crease in the labor participation rate of women (from less than $30 \%$ to about $43 \%$ in the years 1975-1987). This has increased unemployment especially among these groups. However, it is estimated that the situation will change in the future. The proportion of the population made up of young people is estimated to decline, because of decreasing fertility, in all member countries. The number of the elderly is expected to increase. In the EC, it is estimated that in 2025 the population will be $2 \%$ smaller than in 1989 . The population is predicted to decrease in all other countries except Greece and England. (The unification of East and West Germany was not yet taken into account in this forecast.)

Thus, it is estimated that in the EC, especially in its northern member states, unemployment will turn into a labor shortage. It is no longer believed that the arrival of new technology will free much labor, instead it has been predicted that there will be an especially grave shortage of young qualified workers trained in the use of the new technology. Stiff competition for these young people is beginning all over Europe. In order to cope with this situation, the EC's strategy is to continue to raise the labor participation rate of women, - and as in Finland - to educate and employ the chronically unemployed and to make it possible for elderly workers to stay in the labor market longer.

The overall goals of the labor market systems are the same: To simplify the bureaucracy related to migration and to make it safe for the migrant to migrate. The two systems differ substantially from each other in many essential points, however. The freedom of mobility in the Nordic countries is essentially wider than within the EC. This is understandable, because the countries have about the same level of social security, for example, while, in contrast, the differences between the EC-member states are marked.

The common Nordic labor market is based on the right of everyman to be and to go anywhere in the Nordic countries, and to live and to work in any of them he wishes. The basic foundation of this right is the mutual passport union formed by the Nordic countries. In contrast, the EC has no everyman's right allowing settlement in some other country. Any citizen of an EC-country has the right to seek work in another EC-country, but unless he succeeds in finding work in three months, a residence permit necessary for continuing to reside in that country does not have to be granted. One of the four dimensions of the EC, the free mobility of its citizens, has only concerned the employed labor force and practitioners of a profession or an occupation.

The freedom of mobility is gradually being widened, however. The European Community uses the term »The Citizens' Europe», which means the expanding of the freedom of mobility to include all citizens and measures to improve the all-round welfare of its citizens.

Today, Finland does not belong to the EC-labor market, so that when a Finn goes to work in an EC-country, he must obtain a work permit and a residential permit in accordance with the statutes of the country. If the European Economic Area, the EEA, comes into being, the situation will be altered. Then the Nordic countries would apparently be able to retain their freer Nordic labor market, and Finland would then be a member of two dissimilar labor market regions.

\section{The impact of the changes in Eastern Europe}

The changes occurring in Eastern Europe naturally have a great effect on Finland's position. From the viewpoint of the labor market, the mass unemployment 
caused by changing over to a market economy is creating considerable migration pressure on countries with good employment. For Finland, the most problematic are, naturally, the countries closest to her borders, the Soviet Union and Poland. A new passport law is being drafted in the Soviet Union that would apparently make it possible for her citizens to freely leave the country. The law will probably be effective as of the beginning of next year. According to various Soviet assessments, this would lead to $1-3$ million migrant workers desiring to go work in the West. It will be interesting to see what the reaction of the Soviet authorities will be to the emigration of labor, whether it will be allowed in order to decrease the unemployment rate or whether it will be seen as weakening the functioning of the Soviet economy. In the future, the countries of the West, which have spoken out the most at the CSCE on behalf of the right of people to move freely, will themselves have to limit this mobility. It is clear, however, that the development of social conditions in the various parts of Europe is so different that it will not be possible, all at once, to radically unfetter mobility. On the other hand, increasing the exchange of experts and fixed-term practical training is in the interest of both sides, and these are forms that Finland, also, is developing with many countries and regions.

Labor questions related to Eastern Europe will, in the future, quite evidently take an increasingly more prominent role in Finland, as well as in the other Western countries. Finland will probably continue to practice a cautious work permit policy, with the exception of the so-called Soviet Finns, who are considered equal to return migrants, and for whom permits are granted without taking into account so-called labor policy considerations. They form only a tiny drop in the whole sea of the population, however.

\section{Labor mobility in Western Europe}

The volume of migration is essentially determined by the concurrent existence of push factors in the country of departure and pull factors in the country of arrival. Thus far, experience has shown that the removal of legal hindrances to the mobility of labor does not, in itself, increase the mobility of labor from one country to another very much, because the reasons for migration depend on economic, social and demographic factors and on factors related to the values people hold. The largest migrations in Europe after the Second World War have occurred otherwise than within common labor market regions, with the exception of the migration between Finland and Sweden at the end of the 1960s and in the early 1970s. The mobility of labor between the EC-countries has remained at a low level, with only 5 million EC-citizens living in some other EC-country, and of these, less than 2 million are employed. The EC-countries have about 8 million inhabitants coming from non-member countries, over 2 million of whom are employed.

Studies have been made in the European Community about the willingness of people to move to another country to live because of employment. According to an older study, covering the six original EC-countries (Straubhaar 1987), people would prefer to be unemployed in their home district rather than leave in order to seek work. According to a newer survey (Employment in Europe, 1989), 77\% of the citizens of the EC-countries consider it an advantage that they can go and work in another EC-country.

The latter report estimates that the economic situation in Portugal, above all, will lead to intense migration inside the country or to other countries of the Community. In contrast, no great migration pressure is to be seen coming from Italy, Greece 
Table 1. The number of foreign residents in EC member states in 1988.

$\begin{array}{lrcc}\text { Country } & \begin{array}{c}\text { Foreign } \\ \text { residents }\end{array} & \begin{array}{c}\text { of which from } \\ \text { EC countries }\end{array} & \begin{array}{c}\text { Percentage of } \\ \text { EC-nationals }\end{array} \\ \text { Belgium } & 858,650 & 536,836 & 62.5 \\ \text { Denmark } & 136,177 & 26,875 & 19.7 \\ \text { Francel }^{1} & 3,680,100 & 1,577,900 & 42.9 \\ \text { Germany } & 4,489,105 & 1,275,858 & 28.4 \\ \text { Greece } & 216,641 & 107,781 & 49.8 \\ \text { Ireland } & 83,500 & 66,400 & 79.5 \\ \text { Italy } & 407,023 & 89,844 & 22.1 \\ \text { Luxembourg } & . & . . & . . \\ \text { The Netherlands } & 591,847 & 156,901 & 26.5 \\ \text { Portugal } & 94,453 & 25,296 & 26.8 \\ \text { Spain } & 334,935 & 193,312 & 47.7 \\ \text { United Kingdom } & 1,785,000 & 766,000 & 42.9 \\ \text { EC } & 12,677,431 & 4,823,003 & 38.0\end{array}$

1 The data is from the year 1982

2 The data is from the year 1987

Source: Eurostat. Demographic Statistics 1990. Theme 3, Series C. Bruxelles 1990.

or Spain now, due to their more favorable economic development. When it is also taken into account that in the growth of the demand for labor in Western Germany and France, for example, the emphasis is, above all, on qualified and highly trained workers, this decreases the opportunities the unemployed in the countries of the south have for finding employment.

The conclusions the EC-Commission made on the basis of this report are cautious ones. On one hand, people seem to consider it an advantage to be able to go to work in other EC-countries, and the EC is removing bureaucratic barriers to mobility. For some occupational groups there is concurrently both an excess supply and a labor shortage in the Community countries, which will probably increase mobility. Increased economic integration will promote interaction and cooperation, and thus also mobility across borders.

On the other hand, obstacles related to language, knowledge, culture, climate and finding housing prevent mobility. The actual willingness of people to move from one country to another has remained slight compared, for example, to inter-state mobility in the United States. Even mobility in the border areas of the EC has remained slight. In addition, unemployment does not seem to be increasing mobility today, except for qualified workers. The main reason seen for this is improved social security and the housing shortage found in areas with good employment.

The equivalence of degrees is a central issue related to freeing the mobility of the labor force. This is especially timely in the practicing of an occupation which for some reason or another requires a certain degree.

In recent years the $\mathrm{EC}$ has progressed toward more general statutes in the recognition of degrees. As of the beginning of 1991 a directive concerning the general equivalency of university degrees and degrees from certain institutes will be in effect.

Another factor limiting mobility is the ability to speak a language. A worker can be required to know the language his work duties demand, and he can be asked to present a certificate of language ability before commencing employment. There must be a clear connection between the language requirements and the work duties in question, however. 
According to the EC-Commission's interpretation, when an occupation requiring completion of a professional degree is in question, passing a language test may not be set up as a condition for working in this profession. Does this mean that any doctor from an EEA-country may start his own practice in Finland, even if he does not know the language? This question is now being clarified. In the experience of the EC, no actual problems have come up regarding the language question. Who would go to work or practice his profession in a country, where he does not know the language.

In regard to jobs at the municipal and state level, according to the Rome agreement the free mobility of labor does not concern jobs in public administration. The court of the EC, however, whose decisions have an important role in formulating EC-legislature in practice, has interpreted the above-mentioned article to mean that there should be as few restrictions as possible, and that they should only concern positions where the general interests of the state or other public corporations are managed.

Removing the obstacles in the way of mobility is not seen, in itself, to lead to new migration. On the other hand, especially in Southern Europe, there is an existing migration potential, if the developmental strategies mentioned earlier and the local measures for compensating for agricultural jobs fail. Nevertheless, it seems most likely that migration will increase gradually between the member states, and that this migration will focus more on qualified labor.

\section{Finland as a country of immigration}

The linguistic, cultural and housing-related obstacles to mobility are especially great in Finland. There are, of course, several pull factors in Finland, which may cause migration. In order to receive our high-level social and health services, it is worth »dropping in» in Finland. It is not very likely that this will occur to any great extent, however.

Another pull factor is our labor shortage. It will hardly be significant enough to attract workers from other EEA-countries, because, as we noted earlier, there is also a shortage in the other EEA-countries of the same highly-trained professionals as in Finland. In regard to the labor shortage in the low-wage, predominantly female fields (for example, cleaners), it is not likely that there will be much willingness to migrate here, either, because the migration of a family has traditionally been based on the man's job, while the woman is the one who adjusts.

The increasing relocation of Finnish production factors outside Finland may alleviate the labor shortage and thus deflate the pressures toward migration. A general European phenomenon seems to be the transfer of production rather than of workers outside one's borders, when it is a question of occupations requiring fewer qualifications. In addition to Portugal and the Asian countries, the traditional countries of cheap labor, Eastern Europe may rise rapidly to a significant position as a site for locating Finnish production, also.

Because there really are no more labor reserves available in Finland, in order to remove the concurrent existence of unemployment and a labor shortage, Finland must primarily strive to improve the regional and professional meeting of the current work force. Most likely, domestic labor will still have to be supplemented with foreign labor. The amount needed depends a great deal on the development of the hindering and pull factors mentioned earlier and on the successful administration of the areas of policy affecting them. The coming of the EEA-agreement will not open up a stream 
of foreign labor into Finland, however.

Probably only the mobility of those at the executive level, of trained and professional workers, will increase between Finland and the other EEA-countries with integration and the internationalization of enterprises. Instead of traditional migrants, those who migrate will be "professional transients» and professional migrants. Moving will increasingly be part of one's work career, it will be brief and continuous. There will be fewer social problems involved in these moves than with previous migration. The volume of this migration will hardly become very large. On the other hand, from the viewpoint of the labor market, fields that already suffer from a labor shortage will have added problems in replacing those departing on a limited leave. The emigration of highly trained people from Finland should not be seen as a threat, however, for when they return, these international professionals will be bringing back valuable know-how.

Finland must be able to compete for this labor and also to attract highly trained citizens from other countries to Finland to work. We must develop career promotion tracks, intensify recruiting systems and improve the work environment both physically and psychologically. Migration is also limited by housing problems and, for example, schooling arrangements for children. Finland needs more rental housing, moderately-priced owner-possession housing, new forms of housing (cooperatives and right-of-ownership housing), flexibility in the schooling of children, and more language schools and more language schooling in the normal educational institutions. The psychological atmosphere in Finland must be liberated and the salary/price level must correspond to that of the rest of Europe.

Information and the service network available to migrants must be developed. The nation-wide labor office network forms a natural base for this. The goals and organization of Finland's administration of migration and alien affairs should be reanalyzed, because the current disunited system based on administering affairs by granting permits is not enough.

\section{Social security}

The EC's statutes concerning social security correspond, in principle, to the social security agreements Finland has with many European countries, and which are currently applied in questions concerning the inter-state mobility of labor. Their aim is principally a simple one - to guarantee the worker's and the worker's family's social security, regardless of what country in the community he is working in. If the EEA is founded, these social security agreements would be replaced by the EC-statutes. It is also possible that separate arrangements will be retained, if this is justified and to the worker's benefit. Nevertheless, with the coming of the EEA-agreement, problems will arise in fitting together the Finnish system of security, based on housing and the individual, with the system in most EC-countries, based on the employment of the provider. The grounds for security will have to be changed in part, so that the excessive export of benefits from Finland can be prevented.

Despite its simple principles, the application of the EC-statutes on social security will require substantial expertise. The largest European enterprises have their own social security experts, who advise the worker moving to another country on questions related to social security and who tailor a "personal» security for him. The birth of the EEA-agreement would require that Finnish enterprises also spend additional effort on solving these complicated issues, which are made even more acute by the differences in the basic premises of security in Finland and in the EC-countries. 
The rights of the worker have been the focus of intense development in the EC during the last few years. Underlying this is the view of the directorate of the ECCommission and of the majority of the countries that no real economic integration can be achieved without creating some common social foundation. This foundation is needed also in warding off social problems caused by integration (for example, moving production to the country in the Community with the lowest wage level and work safety norms, or so-called social dumping).

Up to now, the statutes concerning the rights of workers have been very highly demanding. The Commission has not been satisfied with taking the average norms of the member countries as the starting point, instead its norms are very strict, and in part go further than in any country in the world so far. When a Finnish firm goes to Europe, it must be prepared for the legislation in its field to be undergoing intense development and that the statutes will be very demanding.

Some of the statutes are considered to be closely associated with the removal of technical obstacles to commerce or to the prevention of distortions caused by competition. Some of the statutes are so-called minimum directives in the area of social policy, regarding which the member states are free to follow higher norms.

\section{Labor legislation}

Regarding labor legislation, the EC's norms are still incomplete, much is still being created. In this area, only three directives are in force in the EC: wage security, the right of the workers in the transfer of a business and collective protection against unilateral termination. These directives are somewhat stricter than the corresponding directives in Finland, thus requiring that the latter be revised.

So far, changing over to European collective labor contracts and to a uniform wage level have only been topics of discussion. It is clear, however, that integration has already now had a unifying effect on collective labor agreements made in different countries and that the wage and other differences now found between the countries will be reduced.

In advancing equality between the sexes, the $\mathrm{EC}$ is making strong progress on the statute level. The current statutes are already more obligating than the corresponding ones in Finland. The same-wage principle emphasizes the active elimination of discrimination, while Finnish legislation emphasizes the prohibition of discrimination, which is only actualized if someone undertakes measures against the actions of the employer. The EC is continuing to develop legislation in this field. In addition, it is has undertaken an action program including dozens of projects advancing equal rights.

In the area of work safety, the EC has passed separate mandatory directives concerning the technical features of machines, equipment and substances and separate minimum directives concerning the work environment.

Legislation concerning the work environment has developed rapidly in the EC during the last few years, and its regulations are, in general, at a good Nordic level. The most noticeable difference concerns inspection requirements. While inspection in Finland focuses mainly on the arrival of products on the market, which is controlled through type approval, in the EC control already begins at the planning and manufacturing stage of the product. This emphasizes the responsibility of the manufacturer for the safety of his product and, regarding market control, the measures demanded of the authorities against inferior products are stronger than those currently required in Finland. 
The work environment directives also include also regulations concerning cooperation among workers regarding work safety.

\section{The cost of social policy}

A common argument made in Finland is that public services, above all those in the field of social policy, cost society entirely too much, and that they weaken Finland's ability to compete, when her economy is having to adjust to tougher international competition. When comparing how much Finland spends on social policy in relation to the EC-countries, for example, the results are surprising. As in the Nordic countries, the EC-countries have been making a strong investment in the creation of a welfare state since the 1950s. For example, in Holland the proportion of the gross domestic product composed by social expenditures is about the same level as in Sweden, over 30\%. These countries are in the vanguard of Europe in the relative proportion of their input. Finland and Norway, again, are about midway in Europe or at about $22-25 \%$ of their gross domestic product. This is less than what Italy, for example, invests in social security out of its gross domestic product. Only in Portugal, Spain and Greece can the level of social expenditures be considered low, but even there it is starting to rise. The differences between the countries are narrowing down, as a whole.

The comparison presented above does not, of course, mean that, for the individual, social security in Finland would be worse than in Italy, because the gross domestic product per person in Finland is substantially higher than in Italy.

Thus, expenditures for social services have not, by any means, been unusually high in Finland, compared to the other developed European countries. On the other hand, social policy expenditures should not be increased without good cause. The aging of the population structure will in itself see to increasing the costs.

Even though Finland's social service expenditures hardly differ from the average European level, the basic premises according to which they are distributed are different. In Finland, as in the other Nordic countries, much has been invested in public services, while in most EC-countries cash payments or income transfers play a significant role. Many services are produced privately in the EC countries. This is typical of Holland, for example.

Neither in the EC nor in the potential EEA will the statutes require a harmonization of how social services are organized. The current EC-directives only concern migrant labor between countries and its social security. Each country can continue to practice its own social policy. An examination of the developmental history of the EC shows that the birth of the community has not resulted in the social security systems of the various countries coming any closer to each other. Thus, in the Europe of the future, there may be different kinds of welfare state areas, where the solutions concerning the organization of services may vary greatly.

For a small country like Finland, keeping up with technological development and the changing of the structure of production will set up great challenges. In order to do well in this competition, Finland must be able to maximize the effectiveness of all its factors which have a role in the competition. How a Nordic welfare state based on public services can fare well in the Europe of the future depends, to a great extent, on how efficient, flexible and willing to serve it is, compared to the private systems preferred in other countries. Thus, it will have to earn its own right to existence. 


\section{The future for a solidary wage policy}

Some factions maintain that moving into a common European market will also require that the market forces take a greater role. The basic foundations of the Nordic welfare state formed by solidary wage policy and a centralized corporate negotiation system between interest groups and the state have outlived themselves. A common market demands that the Nordic countries take a "neoliberal» line, if we want to maintain the ability of our production to rival others in an ever stiffening competition.

It will certainly be harder to continue a solidary wage policy, when competition for well-trained and qualified labor increases throughout Europe. To this group of workers, Finland is a low-wage country, compared to Central Europe, for example. In addition, as we are aware, in fields of production requiring less training, better wages are paid in Finland than in the southern EEA-countries, in particular, which may attract workers to Finland to these fields. Correspondingly, this may lead firms who still have production plants in these fields in Finland to relocate the rest of them in other countries. (In addition to the southernmost countries of the EC, this socalled social dumping equally concerns other countries in the world.) When one also considers the changes in production technology, then the pressures toward increasing the wage differences between different occupational groups and different members of the same groups will grow. Because a solidary wage policy has been one of the foundations of the active labor policy practiced by Finland, the need for change is apparent.

\section{The position of the trade union movement}

With the internationalization of entrepreneurial activity, the role of the national trade unions is a problematic one. There is the risk that there will be fewer opportunities for influence, even if cooperation within a firm were possible for the workers. An additional problem for the trade organizations of Finland, as well as of the other Nordic countries, is that many questions that have been resolved through collective labor agreements come under the sphere of mandatory legislation in the EC. This is understandable, because the role of interest groups in the various EC-member states is very different. In it's report on the EC, the government of Finland emphasized that »interest groups will be provided with the opportunity to participate in decisionmaking in the EEA in questions concerning them». For the time being, the position in the decision-making of the EC of what in EC-slang is called social dialogue is not fully clear yet. However, the development of cooperation under the directorship of the current chairman of the commission has been favorable. One apparent effect is, however, that the activity of the trade union movement will in the future be more and more international.

\section{Conclusions regarding the Finnish welfare state}

Apparently, however, internationalization will not lead to the birth of one single type of European state, an idea supported in many viewpoints, Danish ones, for example. The EC or the EEA will set out certain limiting conditions, within which the different states will still have the opportunity, if they so wish, to choose their own 
strategy for a welfare state. In the future, Europe will probably continue to be made up of different welfare state regions, one of which will be formed by the Nordic countries.

One prerequisite for survival is that production in the $»$ Nordic region or model» is able to compete. It is important that the work begun in the OECD working group on technological development and the changes in production be continued on the national level as a theoretical discussion and that this examination also include internationalization, the ability to compete and the ability of the Nordic welfare state and its mechanisms to function. This discussion should be carried out between research institutes, the Ministry of Labor as well as interest groups.

The EC-Commission's directives and legislative practice are of a high standard concerning the workers. The Nordic countries are no longer at the forefront in this respect. Nevertheless, in many statutes the Nordic countries, and Sweden, above all, have apparently acted as a model when the corresponding EC-directives were being drawn up, although the Commission may have gone further than the Nordic countries regarding their strictness. It is significant that the Nordic countries are attempting, in addition to their legislation, to act even more widely as exporters of their welfare state model to the rest of Europe. We must make our model so good and so capable of competing that the other countries just simply become interested in it, because it produces such good results.

\section{References}

Commission of the European Communities. Directorate General for Employment, Industrial Relations and Social Affairs (1989). Employment in Europe. Luxembourg.

Kajaste, Ilkka (1990). The Impact of 1992 on Finnish Industry. Part I. The identification of sensitive sectors. Discussion paper No. 26. Helsinki: Ministry of Finance, Economics Department.

Kajaste, Ilkka (1990). The Impact of 1992 on Finnish Industry. Part 2. The analysis of competence performance. Discussion paper No. 28. Helsinki: Ministry of Finance, Economics Department.

Koli, Ilse (1988). Suomi ja yhdentyvä Eurooppa (Finland and a unifying Europe). Työvoimakatsaus 31 (3): $3-15$.

Ploug, Niels (1990). Befolkningsvandringer mellem Norden og EF (Migration between the Nordic Countries and EC). Arbejdsnotat. University of Copenhagen.

Siirtolaisuusasiain neuvottelukunta (1990). Suomi ja ihmisten liikkuvuus muuttuvassa Euroopassa (Finland and the mobility of people in a changing Europe). Komiteanmietintö 1990: 46. Helsinki: Työministeriö.

Straubhaar, Thomas (1987). Freedom of movement of labour in a common market. Efta Bulletin 28 (4): 9-12.

Sundqvist, Ulf (1990). Nordisk inkomst- och sysselsättningspolitik - ett utvecklingshinder? (Nordic income and labor policy - a barrier to progress) Konferanserapport. Nordisk Ministerråd, Oslo, 21-21 september 1990. Oslo. 